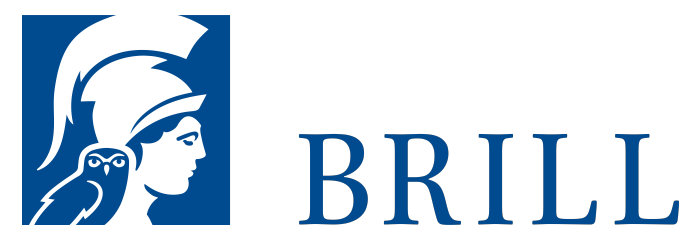

\title{
Satz- und kompositionstechnische Entwicklung der Parodiemesse bis 1540
}

\section{Author: Britta Schulmeyer}

Die Parodiemesse der frühen Neuzeit: Erste umfassende Darstellung der Kompositionstechniken dieser weit verbreiteten Messenart.

Parodiemessen des 15. und 16. Jahrhunderts wurden über mehrstimmige Vorlagen (geistlich und weltlich) der Zeit geschrieben. Wie aber genau gestaltet sich die Übernahme des Vorlagenmaterials? Darauf versucht dieses Buch Antworten zu geben. Weniger die ästhetische Würdigung des Phänomens steht im Mittelpunkt, sondern vielmehr die technisch unglaublich vielfältige, akribische und spannende Arbeit mit vielen, meist auf den zweiten Blick erst sichtbaren Finessen. Detaillierte Untersuchungen von über 6o Parodiemessen der bekanntesten Komponisten der Zeit, zeigen das breite Spektrum kompositionstechnischer Möglichkeiten der Renaissance auf.

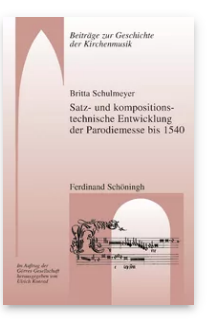

Pages: 283 Seiten, $128 \mathrm{~s} / \mathrm{w}$ Abb., 2 s/w Tab. Language:

\section{German}

Subjects:

General, Theology and

World

Christianity

Publisher: Brill | Schöningh

Series:

Beiträge zur

Geschichte der

Kirchenmusik,

Volume: 22

E-Book (PDF)

Released online: o2 Sep 2019

ISBN: 978-3-

657-78670-1

List price

Paperback

Publication date: 29 Sep 2017

ISBN: 978-3506-78670-8

List price 
Britta Schulmeyer ist promovierte Musikwissenschaftlerin und arbeitet derzeit als wissenschaftliche Mitarbeiterin an der Goethe-Universität Frankfurt am Main.

For more information see brill.com

Order information: Order online at brill.com +44 330 333 0049 | customerservices@brill.com Submission information: brill.com/authors

Titles published by Brill | Fink, Brill | mentis or Brill | Schöningh: +49(o)71 5413279216 | brill@brocom.de 